\title{
Of Promises Delivered and Failed: Post-9/11 America through the Eyes of The Reluctant Fundamentalist by Mohsin Hamid
}

\begin{abstract}
Mohsin Hamid's novel The Reluctant Fundamentalist offers an interesting voice in the discussion about post-9/11 America and shows how a successful immigrant story changes to a racially charged case of ethnic discrimination. Despite the fact that Hamid's protagonist may believe in his successful assimilation into American culture, the general feeling of xenophobia that gripped American society in the wake of the 9/11 attacks forces him to re-evaluate his position. His personal dilemma, oscillating between the desire for material affluence and ethnic loyalty, is presented in a broader context that depicts the world divided along financial and political lines. The conflicting pull between the economic interests lying in the West - represented by the U.S. and the subaltern position of less-developed countries, such as Pakistan - becomes a source of anguish for the protagonist. This paper examines how the borders of conflict shift from public to personal, complicating the issue of identity for Muslim immigrants. The discourse of the war on terror is presented from the perspective of an Other, offering a counter-narrative to the hegemonic narrative of Western culture.
\end{abstract}

Mohsin Hamid's novel The Reluctant Fundamentalist $(2007)^{1}$ offers an interesting comment on post-9/11 America seen through the lens of an outsider. Hamid's protagonist, Changez, possesses the experience of both the Western and Eastern world. This knowledge, however, does not foster his understanding or facilitate his acceptance of diverse ideological and religious systems, but rather makes him cognizant of the existence of irreparable differences between the two. A meeting with an American man in Lahore serves as a pretext for the narrator to address and explore an array of cultural and ideological problems dividing America and Pakistan. The two men spend most of the day in a café, enjoying the atmosphere of the Old Town and savoring local food. In the manner of a dramatic monologue, the protagonist tells his

1 All references are to this edition and are cited by page within the text. 
story, explaining why he has decided to leave America and go back to Pakistan. His unnamed interlocutor is a silent witness who neither confirms nor contradicts the narrator's account but who stands for the Other to whom the narrator explains the Muslim world. As the story unfolds, Changez examines Americans' reactions to the events of $9 / 11$, and his one-sided and personalized version of the dramatic events offers an interesting voice in the discussion about the threat of terrorism in the contemporary world. Bringing his native and immigrant experiences to the fore, Hamid's protagonist challenges the preconceived ideas about who "us" and "them" are, examining the idea of national loyalty. Through a dialogue with the past, the novel explores American prejudices against Muslims and discusses the perception of the United States in the Middle East.

America seems to have delivered its promise to a young Pakistani immigrant who has benefited greatly from its opportunities. Changez's entry into American culture comes with his college enrollment: "I have access to this beautiful campus [...] to professors who are titans in their fields and fellow students who are philosopher-kings in the making" (3). The immersion in the intellectual atmosphere of American academia furnishes him with the belief in individual success: "Princeton inspired in me the feeling that my life was a film in which I was a star and everything was possible" (3). Being one of the only two Pakistani students in his class confirms his success and testifies to the scope of his academic achievement. He lives up to his parents' and his own expectations and stays at the top of his class. America accepts the best international students, providing them not only with excellent educational opportunities and financial aid, but also imbuing them with a set of desired values. What the students are asked in return is to "contribute [their] talents to [American] society, the society [they] were joining" (4). Changez's academic career at Princeton University and later a prestigious and gratifying job foster his conviction of personal success and signify the fulfillment of the American immigrant dream. The young professional profits amply from the intellectual and religious freedom that this country has provided; he eagerly enjoys the material comforts of American life, such as a company card that covers any ostensibly work-related expenses. The ambitious protagonist mimics the ways of financial high-flyers, and a holiday in Greece in the company of young and privileged Americans provides an illusion that he may actually become one of them. As Bjerre points out, these attempts will prove futile, for "[i]t is a story about the inability of an Other to pass as an American" (259). Changez's immersion in American society is illusory and, as he learns after 9/11, instead of the validation of his insider's status, will only bring disappointment and frustration in its wake.

As much as financial gratification enables him to indulge in the rewards of American materialism, he begins to notice the psychological costs of such a life. In time, he starts to question ethical issues involved in his job and feels uncomfortable as an obedient cog in the corporate machine - in line with post-political thinking, he calls himself, first of all, an "Underwood Samson trainee" (34), not a Pakistani American. Business trips abroad make him realize the dire consequences of profit-oriented capitalism; he feels sympathy towards the workers in Manila and, at the same time, he is ashamed of his own ruthless actions. A meeting eye-to-eye with a hostile Filipino driver is like a cold shower: "His dislike was so obvious, so intimate, that it got under my skin" (67). On the one hand, in a gesture of Third World solidarity 
that escapes national confines, Changez recognizes the driver as a fellow victim of American discriminating foreign policy. On the other hand, under the gaze of the driver, he realizes the dubiousness of his own position as an American employee, which awakens his consciousness and instigates his disillusionment with the idea of American success. His growing reluctance to indiscriminately accept and follow the capitalist order opens his eyes to the other side of this activity; Changez realizes that the most important aspect of his job is the ability to cut costs and downsize the workforce to grease the wheels for a buyout. He becomes aware of wide economic disparities between the developed and developing nations, which allow the exploitation of the latter. Singh observes that America reveals its mercantile and authoritarian side from a distance, and "[ $t]$ he myth of the perfect immigrant, as well as the perfect America, is dismantled for Changez in these locations that speak to the complex history of American imperialism - the Philippines, Chile, and finally Pakistan. The idiom of the local, the novel indicates, is often a more powerful agent of change than the globalized narratives of terror and war" (29).

The position of the protagonist as a postcolonial subject is signaled by Juan-Bautista - Changez's client, who reminds him of the story of the Janissaries: "Christian boys [...] captured by the Ottomans and trained to be soldiers in a Muslim army $[\ldots]$ They were ferocious and utterly loyal: they had fought to erase their own civilization, so they had nothing else to turn to" (151). Changez sees himself as a modern-day janissary whose battlefields have been replaced with stock exchanges and spreadsheets: "I knew from my experience as a Pakistani - of alternating periods of American aid and sanctions - that finance was a primary means by which the American empire exercised its power" (156). This realization allows him to make the decision to quit: "The only surprise was that I had required so much time to arrive at my decision" (156). America both attracts and repels him, testing his drive for success against his inner imperative to preserve moral integrity. Even though he is rewarded for his dedication, mainly in material terms, he does not feel truly at ease among his corporate colleagues whose attitude is devoid of ethical qualms. The employees of Underwood Samson (which has, as Morey observes, "the initials U.S." (140)) pursue their daily tasks with devotion equal to those of religious zealots, or fervent ideological activists. This observation brings Changez to the conclusion that American capitalism is an ideological corollary with religious movements in the Middle East. In hindsight, Changez realizes that the corrupt nature of his job and the pursuit of ideals that serve the capitalist system deprive him of a vital part of his identity. He is not willing to renounce the principles that have formed his Pakistani self for the sake of American materialism.

Changez acts as an intermediary between two cultures: his native Pakistani and adopted American. Possessing knowledge of both, he can signal the points of contention that may hinder mutual understanding. Representing an outsider's view, the protagonist enumerates accusations against America: indifference to the rest of the world, lack of concern for the expense the war of revenge costs others, and the assumed and disseminated position of the righteous superpower, which is in fact an imperialistic dominator of the globe. He mocks America's conviction of its special place in world history. In the protagonist's words, his American listener "seemed to be on a mission" (1), where the italicized word no longer refers to a noble attempt at building "the city upon the hill" but rather to instances of ruthless economic, 
military, and ideological colonization of the world. Observing his Princeton friends on holidays, Changez gets annoyed by "[t]he ease with which they parted with money" and by the aura of "self-righteousness in dealing with those whom they had paid for a service" (21), which they emanated. He criticizes the "typically American undercurrent of condescension" (55), which is detectible in dealings with non-Americans, especially those of lesser means. He notices that "the denial of gratification" (69) is mostly un-American since they want to have everything immediately. Americans are generally described as overconfident and arrogant towards others, conducting themselves in the world as if they were the ruling class. For example, Changez identifies his silent interlocutor as American not by his fair complexion or Western clothes, but by his "bearing" (2), defined as an air of self-importance and haughtiness. Moreover, his look of "a seasoned army officer" (6) and his presence in Lahore evokes the possibility of implementing American foreign diplomacy by means of military action. The concept of culture is used here not only to highlight differences between particular groups, but it propels a broader agenda. Mahmood Mamdani explains the phenomenon of 'culture talk': "Culture talk assumes that every culture has a tangible essence that defines it, and then explains politics as a consequence of that essence. Culture talk after 9/11 [...] explained the practice of 'terrorism' as 'Islamic.' 'Islamic terrorism' is thus offered as both description and explanation of the events of $9 / 11$. It is no longer the market (capitalism), nor the state (democracy), but culture (modernity) that is said to be the dividing line between those in favor of a peaceful, civic existence and those inclined to terror" (16-17). Politicizing of cultural differences legitimizes the use of violence, both from the attacker's and victim's perspective.

The juxtaposition of the leading superpower with the struggling Pakistani economy inevitably evokes the gap between wealth and poverty. During a job interview, Changez's difficult financial situation is brought to attention - his "family couldn't afford to send [him] to Princeton without a scholarship" (8). Even if he cannot afford to pay for his American tuition, in Pakistani terms, he is not poor: "Our family home sits on an acre of land in the middle of Gulberg, one of the most expensive districts of this city. We employ several servants, including a driver and a gardener - which would, in America, imply that we were a family of great wealth" (10). Citing this observation, we can recognize the definition of 'wealth,' which shifts depending on the perspective. In line with the popular concept of 'rags to riches,' Changez believes that in America poverty is a cause of shame, especially when he finds himself in the company of affluent young people. Trying to keep up with his colleagues, he "conducted [himself] in public like a young prince, generous and carefree" (11) while keeping three jobs on campus in "infrequently visited locations" (11). American insistence on financial success is contrasted with the Pakistani attention to tradition, history, and the predominant significance of family ties. Changez is proud to remind himself and the rest of the world about his homeland's glorious past: "For we were not always burdened by debt, dependent on foreign aid and handouts; in the stories we tell of ourselves we were not the crazed and destitute radicals you see on your television channels but rather saints and poets - yes - conquering kings" (102). A general economic decline affects his country, causing the pauperization of the society: "We are part of a broader malaise afflicting not only the formerly rich but much of the formerly middle-class as well: growing inability to purchase what 
we previously could" (11). The narrative uses the idea of material prosperity not only to show differences between two economies but also to signal diverse reasons responsible for the imbalanced distribution of wealth. Economic pull factors have always been common incentives for potential migrants, and the fact that the narrator goes to America in search of first-rate education, which is synonymous with higher wages and better standards of living, testifies to their unrelenting viability in the modern world.

Instead of facilitating mutual understanding, cross-cultural experiences might also be a source of confusion. The narrator explains how in an immigrant's mind ethnic loyalties take precedence over an adopted sense of obligation. A general display of American flags after the 9/11 attacks in a symbolic gesture of national unity and solidarity is perceived by Changez as a warning against the potential enemies of the world's leading superpower: "The mightiest civilization the world has ever known; you have slighted us; beware our wrath" (79). What brings Americans comfort in a time of distress is taken for a blatant display of the country's power and supremacy. Moreover, the criss-crossing of cultural boundaries alters one's own vision. That is why, when paying a visit to Lahore, Changez recognizes "the Americanness of [his] own gaze" (124), which concentrates on "how shabby [his] house appeared, with cracks running through its ceiling and dry bubbles of paint flaking off where dampness had entered its walls" (124). By adopting the Other's gaze, the protagonist sees his home in a different, in this case less desirable, way. Darda observes that "[c]onsidering his childhood home as an American valuator might, he cannot see it as one of many conditions sustaining his parents' lives, only a building lacking in market value" (114). However, this state is not permanent and his home becomes familiar again once he reacclimatizes: "I saw my house properly again, appreciating its enduring grandeur, its unmistakable personality and idiosyncratic charm" (125). Changez does not use the opportunity of cross-cultural sampling for personal enrichment, but rather to show the detrimental influence of the Western world on an immigrant's mind. This exposure instigates a feeling of shame about his own poverty and illustrates the complicated meaning of what the "proper" gaze is. Oscillating between familiar and strange, material and spiritual, the narrator draws lines delineating the boundary between the two totalizing categories of West and East.

Hamid's protagonist uses different registers to highlight differences between Pakistani and American parts of his experience. A sensual and affectionate language is used when he talks about his home in Lahore; he confesses: "Princeton made everything possible for me. But it did not, could not, make me forget such things as how much I enjoy the tea in this, the city of my birth, steeped long enough to acquire a rich, dark color, and made creamy with fresh, full-fat milk" (14). Recollections of his family home evoke warmhearted feelings of permanence and safety but at the same time answer the stereotypical notions of a polite Eastern man. In the author's own words: the reason why The Reluctant Fundamentalist is written in this tone with an emphasis on a particular Pakistani accent or dialect of English is because it resonates with many Western preconceptions about Muslims belonging to something that is anachronistic, which is from the past, something overly formalized (Yaqin 46).

Dry language, on the other hand, is used when the protagonist recounts his experiences in America. Then, he talks about competition, work, profit, and money. 
American pragmatism, professionalism, creativity, and efficiency are contrasted with carefree adolescence, the safety of home, and the conviction that if anything happens, family and friends will have his back. America represents his public life, which illustrates how he creates his persona to meet the expectations of others, whereas Pakistan stands for the private realm, locating him within his comfort zone. American experience represents an illusion that requires the protagonist to put on appearances in order to meet its expectations, thus he becomes an American student, employee, and boyfriend. In order to play those roles well, he must suppress everything that does not conform to the desirable model, such as emotional vulnerability, for the sake of practical efficiency. The fact that he, himself, questions the veracity of his own account indicates its fictional character: "I'm, after all, telling you a history. And in history, as I suspect you - an American - will agree, it's the thrust of one's narrative that counts, not the accuracy of one's details" (118). The symbols, such as Underwood Samson (U.S.), Am(Erica), East-West binary and a beard, prompt to read the novel as allegory, further confusing readers as to the authenticity of Changez's confession. Even more misleading is the over-polite tone of the narrative voice, which contrasts with the violent and ominous subject matter. The narrator manipulates his account of what happened, as he tries to control the American whom he suspects to be a secret agent sent to kill him. Over the course of the story, he provides a handful of predictable stereotypical platitudes, implicitly expecting his listener and the readers to verify their meanings. This strategy does not only unsettle and undermine the preconceived notions of otherness but allows the readers to find and forge new ways of thinking.

The silent listener expresses typical Western fears of the exotic and foreign setting; he is uneasy and watchful all the time. In a café, he sits with his back to the wall so that he can keep an eye on what is going on around him, and he is afraid to drink tea in case he might be poisoned. An inability to speak a foreign language prevents his access to and understanding of the culture around him: "You would have been surprised, [not alarmed] by the sweetness of [the waiter's] speech, if only you understood Urdu" (6). Morey claims that the "[1]ack of local knowledge here translates into lack of power as the American is baited about his exposed and lonely position" (141). The American's behavior brings to mind "the behavior of an animal that has ventured too far from its lair and is now, in unfamiliar surroundings, uncertain whether it is predator or prey!" (32). The narrator's portrayal of an American character mirrors his own anxieties: where the protagonist feels safe, the American senses threat, even though Changez tries to dispel his worries by declaring them completely ungrounded. In this way, he acts both as a native informant and the informed, bringing master narrative and counter-narrative together in order to show how they are appropriable by each other. The fact that the anonymous American is denied a voice of his own is significant since his whole characteristic derives from the narrator's perception. In a symbolic reversal of roles, in which the subaltern renders the hegemonic 'mute,' denying a voice to America becomes a gesture of historic justice.

The experiences of 9/11 are an important part of the protagonist's development, as they trigger doubts concerning his assumed identity. While he was watching the towers collapse on TV, he "smiled. Yes, despicable as it may sound, [his] initial reaction was to be remarkably pleased" (72). His initial sense of pleasure caused by the tragedy results from the fact that someone has finally humiliated the biggest world 
power: "I was caught up in the symbolism of it all, the fact that someone had so visibly brought America to her knees" (73). The frustration generated by his desire to fit into American life, all that time carefully hidden from his colleagues, has finally found a vent. In this moment, we can see how much the attainment of the American dream has been costing him and how shallow its grip really is. Fortunately, his worries about his girlfriend Erica come at a convenient time and make it so he no longer has to fake anguish in front of his colleagues.

For the protagonist, 9/11 was a turning point that prompted his turn to radicalism. Pre-9/11 America gives him so much confidence that he could assert: "I was the only non-American in our group, but I suspected my Pakistaniness was invisible, cloaked by my suit, by my expense account, and - most of all - by my companions" (42). Suddenly, Changez finds himself a victim of racial profiling, a terrorist-look-alike who fits the Bush administration's homeland security rhetoric. The hostility and resentment which began to dominate his experience of America now de-familiarize his world, making him feel imperiled and vulnerable. He reports Americans' retaliations against Pakistani immigrants: "Pakistani cabdrivers were being beaten to within an inch of their lives; the FBI was raiding mosques, shops, and even people's houses; Muslim men were disappearing, perhaps into shadowy detention centers for questioning or worse" (94). Next, he hears "tales of the discrimination Muslims were beginning to experience in the business world - stories of rescinded job offers and groundless dismissals" (120). In consequence, he becomes alienated from the world in which he spent four and a half years and which he had so far taken for his own. The dramatic events of 9/11 and the subsequent aura of uncertainty trigger his consciousness, revealing a person struggling with divided allegiances. Familiarity breeds safety, especially when Americans start to question his loyalties or undermine his notion of who he is. This is why he retreats to the friendly territory of his family home.

Hamid's novel illustrates how the events of 9/11 annihilate the protagonist's immigrant hopes, showing how fragile the foundations of these hopes actually were in American reality. Instead of coming to terms with the new post-9/11 world, America is presented as nostalgic about the loss of innocence. "I had always thought of America as a nation that looked forward; for the first time I was struck by its determination to look back" (115). In his vision, the wounded nation withdraws into the past, nurturing its prelapsarian memory. Hence, the protagonist's accusations: "As a society, you were unwilling to reflect upon the shared pain that united you with those who attacked you. You retreated into myths of your own difference, assumptions of your own superiority [...] Such an America had to be stopped in the interests not only of the rest of humanity, but also in your own" (168). The narrator posits that what happened on 9/11 were not irrational and random attacks aimed at destroying an innocent nation, but rather the result of American economic and military policy whose aim is to reinforce American world dominance. By peeling off the personal aspect, he can signal an anonymous and global network of economic relationships responsible for the attacks. Thus, the fight against terrorism is in fact a veiled way to promote and protect American interests around the world.

The protagonist's experiences with America are foreshadowed by his relationship with Erica, who seduces an innocent boy in the same way that American wealth and opportunities seduce a success-hungry graduate. Peter Morey claims that "the 
tentative flowering of her relationship with Changez represents the possibility of East/West rapprochement in the cosmopolitan spaces of New York" (140). Their liaison, however, is doomed to failure since it is based on a lie - he asks her to pretend that he is Chris, her dead lover: "'Pretend I am him,' I said again. And slowly, in darkness and in silence, we did" (105). Changez renounces his own identity in order to encourage her interest in him, a strategy that proves hazardous to building a meaningful relationship since he feels both "satiated and ashamed" (121). Changez wants to be Erica's protector and lover, yet in neither of the roles can he really find himself. The girl, on the other hand, is drawn to his exotic otherness, which makes him stand out from the crowd of similar white, middle-class, American suitors. By the same token, she admires his strong attachment to family, home, and tradition. Since Changez was raised "in an environment too thoroughly permeated with a tradition of shared rituals of mysticism," he believes that "care, affection, and desire of others" (140-141) could be a remedy for Erica's malady, not pills or the sterile atmosphere of an asylum. Changez's American girlfriend, who could provide entry into high society, fails him and withdraws from life. What seemed to have been within his reach, the unattainable golden girl from Park Avenue and a corporate career, disappear, leaving him suspended between desires and reality. Changez's love for Erica ends like his love for America - both remain unrequited. Erica falls into madness just like post-9/11 America falls into a terrorist psychosis - they are presented as equally unable to come to terms with the tragedy. Insanity is compared to religious zealotry since both conditions reject as hegemonic anything other than conformity of attitude; when he sees her, "she glowed with something not unlike the fervor of the devout" (133). While Erica finds comfort in the calm atmosphere of the mental institution and a possible suicide, America evokes myths of national heroism and solidarity, while reminiscing about lost innocence. The girl's dead lover and her inability to cope with personal loss imply the country's nostalgia for the security of a time that is now bygone. Changez's failure at embracing and being embraced by $A m$ (Erica) signifies the Other's failure at finding happiness both in the private and public realm of his immigrant experience. However, the protagonist's name (Changez) implies the possibility of change, which is lacking in the Christian world, symbolically represented by Chris - Erica's dead lover.

Wearing a beard is an act of Changez's rebellion against American post-9/11 policy towards Muslims, as well as symbolic support for his religious and cultural heritage. Growing a beard is a relatively slow process that gives the protagonist time to contemplate the veracity of his decision. In the protagonist's own words: "It was, perhaps, a form of protest on my part, a symbol of my identity, or perhaps I sought to remind myself of the reality I had just left behind...I did not wish to blend in with the army of clean-shaven youngsters who were my coworkers" (130). Through this act of visual othering, he draws attention to himself and his subaltern position, highlighting an individual amidst the global controversy. The beard becomes his personal, embodied, and non-verbal statement about post-9/11 America. It is also a symbol of masculinity, as Bjerre claims: "[h]is beard is one way of asserting his masculinity in the face of the massive racial profiling he is facing" (261). However, the fact that Changez represents a hybrid character obfuscates the matter, bringing his ethnic background into focus. Performing his identity, Changez challenges those who tend to see the world in stereotypes. Wearing a beard is a deliberate and 
outward demonstration of this part of his self that might significantly jeopardize his inclusion into American society. As a visual invitation to mistreatment and social persecution, the symbolic beard draws attention to how easily people tend to pigeonhole others. The beard changes not only his appearance, being the manifestation of the Other, but also shifts his notion of himself by leaning towards the inherited rather than adopted legacy.

Rather than asserting a single central idea, the author provides a cluster of associations with the word 'fundamental.' First of all, there is the oxymoronic 'reluctant fundamentalist' in the title, which implies the unwanted yet inevitable nature of the protagonist's ideological position. In the wake of the 9/11 events, Islam and religious fundamentalism have become key concepts in identifying the enemies of the state. Even though the narrator avoids an explicit religious context, he cannot escape ethnic stereotyping and demonstrates how these labels have come to define who he is. As Singh aptly observes, however, the protagonist's characterization "defies the expectations of fundamentalism as it aligns radicalism with the modern, secular, educated, and privileged Pakistani elite, rather than with the prescriptive pre-modern regressive, illiterate, and intolerant jihadi" (26). The way Changez describes his studies at Princeton University and trainee days at Underwood Samson is reminiscent of the strategies of Islamic fundamentalists: sleep deprivation, total devotion to the cause, focus on one aim, and lack of a private life. Although driven by different goals, religious or ideological zealotry equally take control of an individual's life. Then, there are the fundamentals of the market economy, which are essentially profit-oriented. Wainwright, Changez's colleague, reminds him that he is "working for the man" and that his "deals would go ahead whether [he] worked on them or not. And focus on the fundamentals" (98). Economic fundamentals are viable components of American capitalism, which tend to disregard the human factor altogether, not infrequently ruining workers' lives and unsettling local communities. Economic power is in the novel associated with the myth of American righteousness and superiority. By following its doctrine, the protagonist becomes just another adherent of the oppressive system. Finally, fundamental principles may imply what should be most important for every human being, namely to live a life in peace and dignity. In fact, the importance of blood ties for the protagonist signifies family as the ultimate safe haven amidst the confusion of the modern world.

Hamid's narrative explores two nations divided by unsurmountable cultural and political differences that are fueled by particular and interim goals. The two characters, who embody the idea of male hegemony, are accompanied by cultural symbols of masculine power - economic, corporate, exploitative, authoritarian, dominating, and supreme. The relationship between the narrator and his silent interlocutor is presented in terms of binary oppositions: familiar-alien, relaxed-tense, rich-poor, power-subjugation, predator-prey, advanced technology-tradition, which deem the inherent differences between the two groups to be unbridgeable. For example, watching the TV coverage of an American military retaliation in the Middle East, he is struck by "the mismatch between the American bombers with their twenty-first-century weaponry and the ill-equipped and ill-fed Afghan tribesmen below" (99). He further reflects on the historical changes between the East and the West: "Four thousand years ago, we, the people of the Indus River basin, had cities that were laid out on grids and boasted underground sewers... Now our cities were 
largely unplanned, unsanitary affairs, and America had universities with individual endowments greater than our national budget for education. To be reminded of this disparity was, for me, to be ashamed" (34). According to Morey, numerous references to Pakistani history and culture inform the Western reader, but more importantly, "give a local habitation and a name to a part of the world the West too often sees only as a strategic problem to be solved and a threat to its own regional and international interests" (141). Even though the protagonist is aware of the disparities dividing the two parts of the world he has come to experience, he still fails to establish the reason for his homeland's economic and civilizational downfall. Even if one might blame America for playing the world economy to its advantage, it cannot be held responsible for every failure that has befallen Pakistan in recent centuries. A trip to Rhodes makes Changez realize that the conflict between the East and the West is not a new phenomenon: "Its cities were fortified, protected by ancient castles; they guarded against the Turks, much like the army and navy and air force of modern Greece, part of a wall against the East that still stands. How strange it was for me to think I grew on the other side!" (23). The author illustrates how the personal and the political collide, trapping the protagonist in a situation that fails to deliver a satisfactory outcome; he is caught between cultures and possibilities, weighing his loyalties. His perception of America, however, is fragmentary, as it derives from his involvement only with the highest echelons of American society - the rich, the privileged, and the white. What he fails to realize is that the America he becomes acquainted with is elitist not only to the outside world but also to its own, non-white, less educated and less fortunate citizens.

Hamid's novel shows how the impact of traumatic events on an individual may compel him to become a circumstantial fundamentalist. What the narrative promotes is the claim that an individual is not born a fundamentalist, but circumstances may coerce him into becoming one. The global becomes the private when political concerns trigger personal and moral choices. An individual, liberal consciousness is confronted with structural, global problems of an ethical, economic, and political nature. What the author leaves out, however, is the power of individual consciousness, the conviction of what is right and wrong that prevents unlawful and immoral behavior regardless of the circumstances. While social and political events prompt his maturity, Changez decides to leave America with its opportunities and promises of a better life in order to support his family and live among his people. Loyalty to his own kind takes precedence over the particularity of personal goals, especially when a sense of individual happiness is at stake. The awareness of the fact that his family back home might suffer from a military conflict whose active participant is America helps him to decide what is really important in life. The novel forwards the claim that one's obligation to family and homeland will always trump the allure of materialistic rewards. In fact, immersion in American life does not seem to have fostered his acceptance or appreciation of the Other, but proved a catalyst for his sense of local patriotism. Back in Pakistan, Changez engages in an anti-American campaign, organizing demonstrations "for greater independence in Pakistan's domestic and international affairs" (179). It is not clear, however, whether he becomes a terrorist or just exercises his right to free speech. American openness, freedom, and opportunities are presented as deceptive since they come at a price that is not worth being paid, the narrative seems to suggest. 
Hamid's novel is an interesting voice in a discussion about the contemporary world, which tries to account for both Western and Eastern political and cultural realities. We are presented with a set of stereotyped notions that tend to shape our knowledge about the world. Even though the reader may forge an emphatic connection to the protagonist, its viability is threatened by complications resulting from the engagement with Otherness. The novel ends with the narrator escorting an American back to his hotel where they see a group of men who begin to confront them. In the style of The Arabian Nights, the end of the story might signify the death of the storyteller, and the readers are left to wonder what the men's intentions might be. It is not clear who should feel more endangered: the American visitor/secret agent wandering around the dimly-lit streets of Lahore, or the Pakistani political activist who openly expresses his frustration with American foreign policy. In the protagonist's words, one "should not imagine that we Pakistanis are all potential terrorists, just as we should not imagine that you Americans are all under-cover assassins" (183). The juxtaposition of two perspectives allows the author to question the binary opposition between good and evil as one of the buttresses of ideological thought in Western culture. Hamid's narrative demonstrates how well racial stereotyping is ensconced in our consciousness, fortified by media coverage and official propagan$\mathrm{da}$, and how difficult it is to produce a convincing, literary alternative to the realities of life. Changez is not a religious extremist, nor does his political awakening instigate in him hatred towards Western materialism and immorality, both of which are commonly attributed to Islamic radicals. Susan Faludi's book The Terror Dream: Fear and Fantasy in Post-9/11 America (2007) explores the dominant discourse from a feminist standpoint, demonstrating how the gendering of the American post-9/11 conception of national security helped to construct and disseminate the protective myth of male heroism. Changez's experience of immigration, however, signals a changing notion of identity, which is no longer informed solely by one nationality. Hamid's transnational story features a protagonist whose identity is open to negotiation and renegotiation prompted by changing circumstances. Shifting between the immigrant, the native, and the cosmopolitan, the protagonist refuses to be fixed by the Western gaze, which is informed by binary oppositions.

Elaborating on the commercial and capitalistic aspects of the global economy and its consequences for less developed countries, Hamid's novel can be seen as undermining the exceptionalist view of $9 / 11$ as a unique event. The narrative provides a cause-and-effect sequence which explains the rationale behind the attacks from the Other's perspective. Its indeterminate ending, however, leaves open the possibility of a space in which the cultural, the political, and the territorial are brought together. The author does not offer a solution or even a path towards mutual understanding, but signals those areas where the discrepancies are at their highest. Suffering, as presented in the novel, relates both to the victims of the 9/11 attacks and those affected by America's retaliatory measures, thus refusing to express an unequivocal ethical position. Hamid's novel contrasts and compares two different sets of cultural practices in order to show where probable points of contention might be found, but the conclusion suggests that the forces of assimilation lose when confronted with the power of inherently particular differences, especially when they are subject to influences arising beyond their borders. 


\section{References}

Bjerre, Aervold Thomas. "Post-9/11 Literary Masculinities in Kalfus, DeLillo, and Hamid." Orbis Litterarum 67: 2012 (3): 241-266.

Darda, Joseph. "Precarious World: Rethinking Global Fiction in Mohsin Hamid's The Reluctant Fundamentalist." Mosaic 47: 2014 (3): 107-122.

Faludi, Susan. The Terror Dream: Fear and Fantasy in Post-9/11 America. New York: Metropolitan Books, 2007.

Hamid, Mohsin. The Reluctant Fundamentalist. New York: Harcourt, 2007.

Mamdani, Mahmood. Good Muslim, Bad Muslim: America, the Cold War and the Roots of Terror. New York: Three Leaves, 2004.

Morey, Peter. "'The Rules of the Game Have Changed': Mohsin Hamid's The Reluctant Fundamentalist and Post-9/11 Fiction." Journal of Postcolonial Writing 47: 2011 (2): 135-146.

Singh, Harleen. "Insurgent Metaphors: Decentering 9/11 in Mohsin Hamid's The Reluctant Fundamentalist and Kamila Shamsie's Burnt Shadows." Ariel: A Review of International English Literature 43: 2012 (1): 23-44.

Yaqin, Amina. "Mohsin Hamid in Conversation." Wasafiri 23: 2008 (2): 44-49. 